\author{
Abstracta Iranica \\ Abstracta Iranica Revue bibliographique pour le domaine irano-aryen \\ Volume 42-43 | 2021 \\ Comptes rendus des publications de 2019-2020
}

\title{
Giuseppe Labisi. "Squinches and Semi-domes between the Late Sasanian and Early Islamic Periods"
}

\section{Parsa Ghasemi}

\section{CpenEdition}

Journals

Electronic version

URL: https://journals.openedition.org/abstractairanica/53341

DOI: 10.4000/abstractairanica.53341

ISSN: 1961-960X

Publisher:

CNRS (UMR 7528 Mondes iraniens et indiens), Éditions de l'IFRI

\section{Electronic reference}

Parsa Ghasemi, "Giuseppe Labisi. "Squinches and Semi-domes between the Late Sasanian and Early Islamic Periods"',', Abstracta Iranica [Online], Volume 42-43 | 2021, document 61, Online since 30

December 2021, connection on 14 December 2022. URL: http://journals.openedition.org/ abstractairanica/53341 ; DOI: https://doi.org/10.4000/abstractairanica.53341

This text was automatically generated on 14 December 2022.

All rights reserved 


\title{
Giuseppe Labisi. "Squinches and Semi-domes between the Late Sasanian and Early Islamic Periods"
}

\author{
Parsa Ghasemi
}

\section{REFERENCES}

Giuseppe Labisi. "Squinches and Semi-domes between the Late Sasanian and Early

Islamic Periods”, Iran 58 (2), 2020, p. 236-249.

1 This paper investigates the classification and typological evolution of "squinche", an Iranian architectural feature, employed in many buildings, in Mesopotamia and Iran, dated to the late Sasanian and early Islamic periods. G. Labisi's study of the squinches on the semi-domes or "kāna pūshs" shows that the early examples of squinches were used in the late Sasanian and the early Islamic architecture such as Qusayr, Kušk-e Ardašīr (in Bozpar, near the tomb of Gur-e Dokttar) and Sarvestān, however, its origin remains unknown (p. 246). The early Islamic squinches related to semi-domes are documented in nine buildings that are located in Bilād al-Šām, Iraq, and Iran. During the Umayyad and Abbasid periods, this model appeared in the Near East in buildings with a Persian influence. While most of the studied squinches support semi-domes, there exists a few squinches placed in niches (e.g., in Sarvestān) and between the span of the diaphragm arches and the supporting walls (Qasr al-Karāna and Ukaidir) (p. 245). The squinches associated with semi-domes in the Islamic period are frequently found in three types of monuments: qasr, dār al-imāra or dār al-Kilāfa, and mosque.

2 Labisi argues that the sawtooth motif appears to have been a popular decorative feature of the late Sasanian and Umayyad architecture. Although concentric arches were used from the Sasanian period through the Abbasid era, concentric circles were only utilized in the Umayyad and Abbasid architecture (p. 247). 
3 Labisi's work on squinches is comprehensive. However, the date of some discussed buildings (e.g. Kušk-e Ardašĩr, p. 238) cannot be accurately determined without the aid of archaeological excavation. Consequently, it is exceedingly difficult, if not impossible, to reliably establish the evolution of squinches. The chronology of the Sarvestān building is established based on radiocarbon dating of only three wood samples; one sample taken from the debris in the northeast corner of room 1 and the two other from the walls of rooms 9 and 10 (cf. AbstIr 40-41, 3.2.3, n 53. M. Djamali et al. "On the Chronology and Use of Timber in the Palaces and Palace-like Structures of the Sasanian Empire in "Persis", SW Iran"). However, the radiocarbon analysis of the timber does not provide a sufficient argument for dating the building's construction, as the timbers may also suggest a date for the reparation of the building in the transitional era. Interestingly, in a new publication on the dating of this building, Jamali and his colleagues (in Archaeometry 2021) agree with our idea: the mid-seventh century CE "may represent a restoration phase or the resumption of the construction works already initiated during the Sasanian period". Furthermore, incomplete archeological test excavations (cf. A.R. Askari Chaverdi, "Archaeological Excavations in the so-called 'Palace of Sāsān' at Sarvistān, Fars." Sasanika Archaeology (3) E-Sasanika, 2012, p. 1-5. Available at: https://sites.uci.edu/sasanika/2012-2/) in the previous decade did not reveal any evidence about the date of the earliest construction phase of the building.

\section{AUTHORS}

\section{PARSA GHASEMI}

Doctorant Archéologie, Université Paris-Nanterre 